\title{
Quality optimization of ring spun yarns produced from blends of regenerated cellulosic fibres with cotton and polyester
}

\author{
DOI: $10.35530 / I T .070 .04 .1630$
}

ESIN SARIOĞLU

\section{REZUMAT - ABSTRACT}

Optimizarea calității firelor filate cu inele produse din fibre celulozice regenerate în amestec cu fibre de bumbac și de poliester

Fibrele celulozice regenerate sunt utilizate în principal în amestecurile de bumbac și poliester cu diferite proporții, pe diferite sisteme de filare, pentru a satisface cerințele specifice ale consumatorilor din industria textilă. Acest studiu realizează o analiză a proprietăților și optimizarea calității firelor filate cu inele, cu fineţea de 19,7 tex, din fibre celulozice regenerate Viloft $\circledast$, ProModal® și bambus în amestec cu fibre de poliester și de bumbac în proporție diferită (100\%, $67-33 \%, 50-50 \%, 33-67 \%)$. Proprietățile firelor, cum ar fi rezistența la tracțiune și alungirea, neuniformitatea, imperfecțiunile și pilozitatea au fost evaluate și comparate pentru a determina influenţa tipului de amestec, tipului de fibră și raportului de amestec. Mai mult, metoda de optimizare numerică a fost dezvoltată pentru a estima parametrii optimi ai calității firelor pentru cele mai bune variabile de răspuns ale următoarelor proprietăți: rezistența la tracțiune și alungirea, neuniformitatea, imperfecțiunile și pilozitatea.

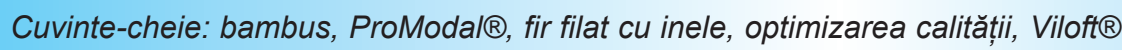

Quality optimization of ring spun yarns produced from blends of regenerated cellulosic fibres with cotton and polyester

Regenerated cellulosic fibres are mainly used with the blends of cotton and polyester with different proportion on different spinning systems to meet specific consumer demands in textile industry. This study conducts the properties and quality optimization of 19.7 tex ring spun yarns made from Viloft ${ }^{\circledR}$, ProModa ${ }^{\circledR}$ and Bamboo regenerated cellulosic fibres blended with polyester and cotton at different proportion (100\%, 67-33\%, 50-50\%, 33-67\%). Yarn properties such as tensile strength and elongation, unevenness, imperfection index and hairiness were evaluated and compared to determine the effects of blend type, fibre type and blend ratio. Furthermore, numerical optimization method was developed to estimate optimum yarn quality parameters for the best response variables of tensile strength and elongation, unevenness, imperfection index and hairiness properties.

Keywords: Bamboo, ProModa ${ }^{\circledR}$, ring spun yarn, quality optimization, Viloft $^{\circledR}$

\section{INTRODUCTION}

To respond consumer demands in textile industry, producers have been focused on acceptable quality and cost of producing yarns. Blending of different fibres is a very common practice to improve better characteristics of fabrics such as drape properties, comfort ability, durability, dyeability, etc. [1-2]. Many researchers have been concerning about blending of different kinds of fibres, proportion and blended yarn characteristics produced on different spinning systems that is ring, open-end, air-jet, friction and vortex. Blending of different kinds of fibres is widely used to reveal new alternative functional products and to improve the performance and the aesthetic qualities of yarns and fabrics [2]. Approximation of physical and mechanical properties of blended yarns has also been studied by various researchers [3-8].

There are various regenerated cellulosic fibre alternatives to enhance the performance of yarn and fabrics. Kilic et al. [9] compared the structural, physical and mechanical properties of cotton-Tencel and cotton-ProModal ${ }^{\circledR}$ blended ring, compact and vortex spun yarns with different blend ratios. They stated that the effect of spinning system is statistically significant on yarn unevenness, imperfections, diameter, density, roughness and roundness, except neps of yarn. By increasing presence of regenerated cellulosic fibre content, it was found that unevenness, imperfections, diameter and roughness values decreased whereas tenacity, elongation, density and shape values increased. When considering the materials used, cotton-ProModal ${ }^{\circledR}$ blended yarns had better structural and physical properties than cottonTencel ${ }^{\circledR}$ blended yarns; however, these yarns had lower mechanical properties. Demiryürek et al. [10] investigated the thermal properties such as thermal conductivity, thermal diffusivity, thermal absorptivity, thermal resistance, moisture, and also air permeability of $\mathrm{Viloft}^{\circledR}$-cotton and $\mathrm{Viloft}^{\circledR}$-polyester single- jersey and $1 \times 1$ rib knitted fabrics. It was found that fabrics made from higher proportion of $\mathrm{Viloft}^{\circledR}$ fibres having flat cross-section and crenulated surface improved thermal characteristics. On the other hand, because of its flat cross-section that tends to protrude the fibres from main body of the yarn, higher Viloft ${ }^{\circledR}$ content in the yarn showed higher hairiness property 
[11]. Atasagun et al. analyzed physical, mechanical and transfer properties of $1 \times 1$ rib fabrics made by blending Viloft ${ }^{\circledR}$ fibre, natural, synthetic, and functional fibres [12]. As also understood from the studies above, regenerated cellulosic fibres were blended with especially cotton and polyester which are commonly used commercially to evaluate the performance of yarns and fabrics by changing raw materials, blend ratios, yarn count, yarn spinning systems etc. North compared the comfort and fabric performance of single-jersey fabrics containing Viloft ${ }^{\circledR}$ fibres that is in $100 \%$, in blends with cotton, in blends with viscose, in blends with Modal and with other cellulosic fibres [13]. He concluded that fabrics containing $100 \%$ Viloft $^{\circledR}$ fibres obtain the highest wearer comfort rating among the fabrics tested. In addition, fabrics containing Viloft ${ }^{\circledR}$ fibres contributed the thermal insulation and wearer comfort properties, as well. Viloft ${ }^{\circledR}$ fibre is mainly used with blends of polyester and cotton in the market and naturally soft and guarantee outstanding wearer comfort. The specialty of $\mathrm{Viloft}^{\circledR}$ has exceptional properties due to its special unique flat cross-section with a crenellated surface. Yarns made of Viloft ${ }^{\circledR}$ contain up to $70 \%$ air gap and fabrics using Viloft ${ }^{\circledR}$ feel soft and light as a feather on the skin and these fibres are of $100 \%$ natural origin and are manufactured from renewable materials. They are also $100 \%$ biodegradable and so they complete the natural cycle [14]. ProModal ${ }^{\circledR}$ consists of a blend of Modal ${ }^{\circledR}$ and Tencel ${ }^{\circledR}$ fibres that combines Modal's soft hand with Tencel's moisture absorption, skin-sensitive properties and strength [15]. Fabrics rich of ProModal ${ }^{\circledR}$ are used for activewear, casualwear, intimate apparel and home textiles [16]. In addition to these fiber types bamboo fibre is also a kind of regenerated cellulosic fibre made from bamboo pulp. Bamboo can be spun alone or with the blend of other fibres such as rayon, cotton, wool, silk, modal, etc. with regard to the required quality of the products [3-7]. Bamboo fibre contributes the tenacity, thermal conductivity, resistivity to bacteria and high water and perspiration adsorption of textile products [17].

In the light of the previous studies, in this study, quality parameters such as tensile strength and elongation, unevenness, imperfection index (IPI) and hairiness properties of cotton and polyester yarns blended with regenerated cellulosic fibres at different proportions were investigated statistically at $95 \%$ confidence interval. In contrast to earlier research, numerical method was conducted to estimate the quality optimization of these yarns regarding with yarn tensile strength and elongation, unevenness, imperfection index (IPI) and hairiness properties.

\section{EXPERIMENTAL PART}

\section{Material}

In this study, Viloft ${ }^{\circledR}$, ProModal ${ }^{\circledR}$ and bamboo regenerated cellulosic fibres were selected owing to their common and commercial usage. Cotton and polyester fibres were blended with these regenerated cellulosic fibres at three different ratios in order to determine the physical and mechanical properties of ring spun yarns. Meanwhile, pure regenerated cellulosic fibres, polyester and cotton yarns were also manufactured. The physical properties of fibres used in this study are illustrated in table 1. Cotton fibre has 4.5 micronaire value and $30 \mathrm{~mm}$ length. Thus, 19.7 tex $100 \%$ Viloft $^{\circledR}, 100 \%$ ProModal $^{\circledR}$, 100\% Bamboo, 100\% Cotton and $100 \%$ Polyester yarns, polyester/Viloft ${ }^{\circledR}$, polyester/ProModal ${ }^{\circledR}$, Polyester/bamboo, cotton/ Viloft ${ }^{\circledR}$, cotton/ProModal ${ }^{\circledR}$ and cotton/bamboo ring spun yarns, blended in three different proportion (67-33\%, 50-50\% and 33/67\%) were produced.

Table 1

PHYSICAL PROPERTIES OF FIBRES USED IN THE STUDY

\begin{tabular}{|c|c|c|}
\hline Raw material & $\begin{array}{c}\text { Linear density } \\
\text { (dtex) }\end{array}$ & $\begin{array}{c}\text { Staple length } \\
\text { (mm) }\end{array}$ \\
\hline Polyester & 1.3 & 32 \\
\hline Viloft $^{\circledR}$ & 1.9 & 38 \\
\hline Promodal $^{\circledR}$ & 1.3 & 38 \\
\hline Bamboo & 1.5 & 38 \\
\hline
\end{tabular}

Fibers were prepared in the blowroom separately and were blended and processed by three drawing passages in the drawing process in accordance with blend ratios. Eight doublings and eight times drafts were performed in all drawing passages in order to make blends more homogeneous. Roving with 656 tex linear density was used to produce 19.7 tex ring spun yarns at the same production parameters (10000 rpm spindle speed, $\alpha \mathrm{e}=3.7$ ).

\section{Method}

The yarn tests were carried out under standard laboratory conditions $\left(20 \pm 2^{\circ} \mathrm{C}\right.$ and $\left.65 \pm 4 \%\right)$ after the samples had been conditioned for $24 \mathrm{~h}$ [18]. Hairiness, unevenness, imperfections values of yarns were determined by using Uster ${ }^{\circledR}$ Tester 4 at $400 \mathrm{~m} / \mathrm{min}$ test speed all through 2.5 minutes [19]. Uster ${ }^{\circledR}$ Tensorapid device was used to measure tenacity and elongation values at $5 \mathrm{~m} / \mathrm{min}$ test speed and $500 \mathrm{~mm}$ gauge length [20].

The results expressed as means of all assays for polyester and cotton blend were compared separately using 'factorial' analysis in order to determine analysis of variance (ANOVA) by means of Design Expert software version 11 (STAT-EASE Inc., Minneapolis, US) at 0.05 significance level. In addition numerical optimization technique was used for the assessments of desirability approach. Independence levels of parameters were chosen as blend type (Polyester and Cotton), fibre type $\left(\right.$ Viloft $^{\circledR}$, ProModal ${ }^{\circledR}$ and Bamboo) and blend ratio $(100 \%, 67 / 33 \%, 50 / 50 \%$, $33 / 67 \%)$. The process response variables were selected as tenacity, elongation, unevenness, IPI and hairiness which are the most important yarn quality parameters. 


\section{RESULTS AND DISCUSSION}

\section{Tensile strength and elongation properties}

The tenacity graphs of polyester and cotton blended yarns with $\mathrm{Viloft}^{\circledR}$, ProModal ${ }^{\circledR}$ and Bamboo with different blend ratio are illustrated in figure 1 . When polyester blend yarns are taken into consideration, it is easily seen that polyester rich blended yarns have higher tenacity but not for cotton blend yarns. Polyester yarn tenacity is higher than that of pure cotton yarn; it is obvious that synthetic yarn has higher tenacity than natural yarn. It is seen in figure 1, the increasing the regenerated cellulosic fibre content affects the tenacity of blended yarns positively for cotton-ProModal ${ }^{\circledR}$ blended yarns [9]. Among the regenerated cellulosic yarns $100 \%$ ProModal ${ }^{\circledR}$ yarn has the highest tenacity value, while $100 \%$ Viloft $^{\circledR}$ yarn has lowest value. Although Viloft ${ }^{\circledR}$ fibre has highest linear density ( 1.9 dtex) and there are more fibres within the yarn structure, tenacity was obtained as lowest because of the fibre properties. When the effect of the blend ratio changes for cotton-bamboo blended yarns, figure 1 indicates that $100 \%$ bamboo yarn and $100 \%$ cotton yarn has a higher tenacity than blended yarns.

Table 2 shows ANOVA results for response surface 2FI Model for tenacity. It is seen that blend type, fibre type and blend ratio parameters have statistically significant effects on tenacity $(p<0.0001)$ with higher $\mathrm{R}$

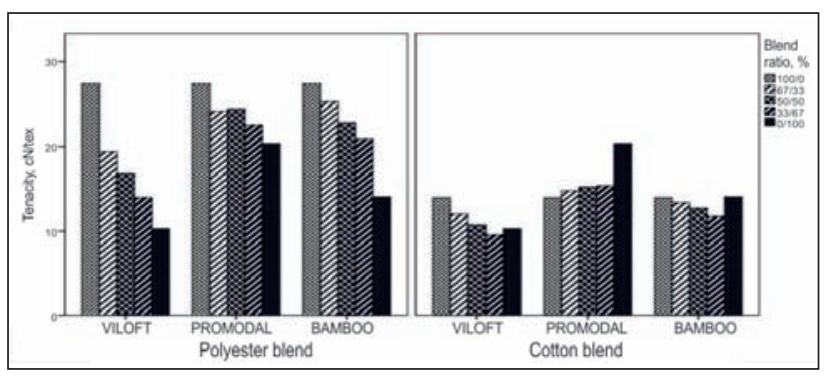

Fig. 1. Tenacity values of blended yarns

Table 2

ANOVA RESULTS FOR RESPONSE SURFACE 2FI
MODEL FOR TENACITY

\begin{tabular}{|l|c|c|c|c|c|}
\hline Source & $\begin{array}{c}\text { Sum of } \\
\text { square }\end{array}$ & DF & $\begin{array}{c}\text { Mean } \\
\text { square }\end{array}$ & F value & $\boldsymbol{p}$-value \\
\hline Model & 921.45 & 9 & 102.38 & 79.66 & $<0.0001$ \\
\hline $\begin{array}{l}\text { A-Blend } \\
\text { Type }\end{array}$ & 446.76 & 1 & 446.76 & 347.61 & $<0.0001$ \\
\hline $\begin{array}{l}\text { B-Fibre } \\
\text { Type }\end{array}$ & 148.10 & 2 & 74.05 & 57.62 & $<0.0001$ \\
\hline $\begin{array}{l}\text { C-Blend } \\
\text { Ratio }\end{array}$ & 117.93 & 1 & 117.93 & 91.76 & $<0.0001$ \\
\hline AB & 9.52 & 2 & 4.76 & 3.70 & 0.0428 \\
\hline AC & 141.08 & 1 & 141.08 & 109.77 & $<0.0001$ \\
\hline BC & 58.06 & 2 & 29.03 & 22.59 & $<0.0001$ \\
\hline Residual & 25.70 & 20 & 1.29 & & \\
\hline Cor Total & 947.16 & 29 & & & \\
\hline
\end{tabular}

industroia textillă

square value of $97 \%$. So it can be said that these all parameters explain the tenacity with the higher $\mathrm{R}$ square. Fibre blend ratio influenced yarn tenacity and this result is expected and reported from some other researchers $[6,9,11,21]$. The most effect size of independent parameters on tenacity is blend type with highest $F$ value.

As regards to fibre type and blend ratio impact on yarn elongation for both polyester and cotton blend types of blended yarns, seen in figure 2, higher yarn elongation could be attained with the addition of a fibre having higher elongation. This situation seems to be true for all cases. Regenerated cellulosic fibre content contributes the breaking elongation of cotton blended yarns positively. They all have higher breaking elongation than that of pure cotton yarn. Pure yarns have a compact structure, thus the elongation increases [11]. A significant increase was observed after $50 \%$ blend ratio for cotton blended yarn. On the other hand, for polyester blend yarns; elongation values do not exhibit regular tendency for all fibre types, however, elongation changes negatively or positively according to the fibre type (ProModal ${ }^{\circledR}<$ Viloff $^{\circledR}<$ Bamboo).

Table 3 illustrates ANOVA results for response surface Quadratic Model for elongation. Blend type has also highest magnitude of effect on yarn elongation

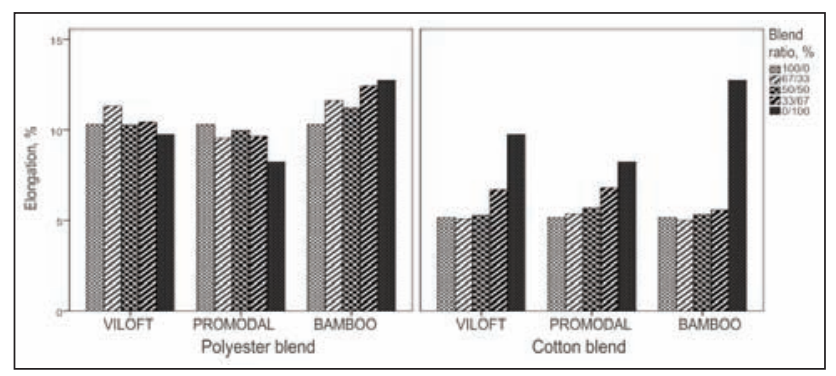

Fig. 2. Elongation values of blended yarns

Table 3

ANOVA RESULTS FOR RESPONSE SURFACE QUADRATIC MODEL FOR ELONGATION

\begin{tabular}{|l|c|c|c|c|r|}
\hline Source & $\begin{array}{c}\text { Sum of } \\
\text { square }\end{array}$ & DF & $\begin{array}{c}\text { Mean } \\
\text { square }\end{array}$ & F value & $\boldsymbol{p}$-value \\
\hline Model & 196.44 & 10 & 19.64 & 22.34 & $<0.0001$ \\
\hline $\begin{array}{l}\text { A-Blend } \\
\text { Type }\end{array}$ & 127.32 & 1 & 127.32 & 144.77 & $<0.0001$ \\
\hline $\begin{array}{l}\text { B-Fibre } \\
\text { Type }\end{array}$ & 9.00 & 2 & 4.5 & 5.12 & 0.0167 \\
\hline $\begin{array}{l}\text { C-Blend } \\
\text { Ratio }\end{array}$ & 16.77 & 1 & 16.77 & 19.07 & 0.0003 \\
\hline$C^{2}$ & 6.94 & 1 & 6.94 & 7.89 & 0.0112 \\
\hline AB & 3.33 & 2 & 1.67 & 1.89 & 0.1779 \\
\hline AC & 23.84 & 1 & 23.84 & 27.11 & $<0.0001$ \\
\hline BC & 9.24 & 2 & 4.62 & 5.25 & 0.0153 \\
\hline Residual & 16.71 & 19 & 0.88 & & \\
\hline Cor Total & 213.16 & 29 & & & \\
\hline
\end{tabular}


with the $\mathrm{F}$ value of 144.77 . All three independent variables have significant effect on elongation with the corresponding $p$ value $<0.05$, however, it was found that the interaction of blend type and fibre type has not statistically significant effect $(p>0.05)$. R squared was determined as higher value of $92 \%$; therefore the quadratic model can be regarded as an appropriate model.

\section{Unevenness}

Yarn evenness can be defined as the variation in weight per unit length of the yarn or as the variation in its thickness. The thickness variation of a yarn is measured by a measuring capacitance and the unevenness is always expressed as between successive lengths and over a total length [22]. Here, $\mathrm{CVm} \%$ value gives a variation of mass for yarns (figure 3). Among some yarns $\mathrm{CVm} \%$ value is the highest for $100 \%$ Viloft $^{\circledR}$ yarn, however, the lowest for 100 $\%$ ProModal $^{\circledR}$ yarn, as the presence of regenerated cellulosic fibre in the yarn structure affects the unevenness and this change is seen obviously for polyester-Viloft ${ }^{\circledR}$ and cotton-Viloft ${ }^{\circledR}$ blended yarns. The increase in unevenness with an increase of Viloft ${ }^{\circledR}$ content is clearly visible. Unevenness in blended yarns depends on fibre length, fibre irregularity, length uniformity etc. in the cross section of the yarn.

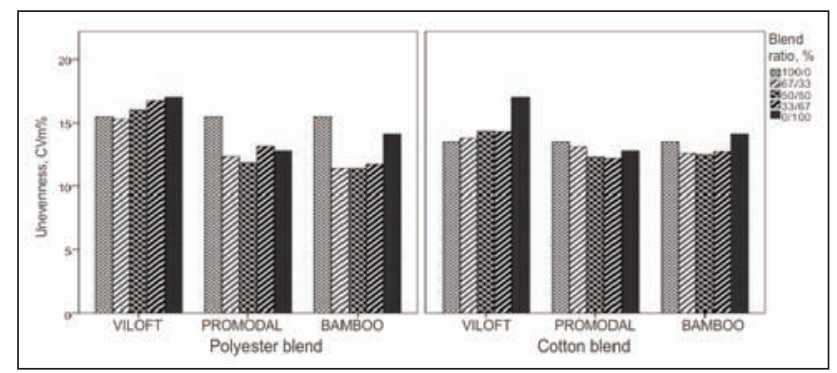

Fig. 3. CVm\% variation of polyester and cotton blended yarns

Table 4

\begin{tabular}{|l|c|c|c|c|c|}
\hline \multicolumn{5}{|c|}{ ANOVA RESULTS FOR RESPONSE QUADRATIC } \\
MODEL OF Cvm\% OF YARNS \\
\hline Source & $\begin{array}{c}\text { Sum of } \\
\text { square }\end{array}$ & DF & $\begin{array}{c}\text { Mean } \\
\text { square }\end{array}$ & F value & $\boldsymbol{p}$-value \\
\hline Model & 66.74 & 10 & 6.67 & 9.58 & $<0.0001$ \\
\hline $\begin{array}{l}\text { A-Blend } \\
\text { Type }\end{array}$ & 2.85 & 1 & 2.85 & 4.09 & 0.0574 \\
\hline $\begin{array}{l}\text { B-Fibre } \\
\text { Type }\end{array}$ & 36.71 & 2 & 18.36 & 26.33 & $<0.0001$ \\
\hline $\begin{array}{l}\text { C-Blend } \\
\text { Ratio }\end{array}$ & 0.30 & 1 & 0.30 & 0.44 & 0.5163 \\
\hline C 2 & 12.13 & 1 & 12.13 & 17.40 & 0.0005 \\
\hline AB & 4.03 & 2 & 2.01 & 2.89 & 0.0802 \\
\hline AC & 1.58 & 1 & 1.58 & 2.26 & 0.1489 \\
\hline BC & 9.14 & 2 & 4.57 & 6.55 & 0.0069 \\
\hline Residual & 13.24 & 19 & 0.70 & & \\
\hline Cor Total & 79.99 & 29 & & & \\
\hline
\end{tabular}

Moreover, Viloft ${ }^{\circledR}$ has an irregular cross section that influences the variations in the cross section of the blended yarn. This is even the same for other ProModal $^{\circledR}$ and bamboo yarns used for this study in different blend ratio with both polyester and cotton.

Table 4 displays the ANOVA results for response Quadratic Model of Cvm\% of yarns. Obtained between $\mathrm{CVm} \%$ and independent variables, blend type and blend ratio do not have statistically significant influence on unevenness with $p>0.05$. It seems that only regenerated cellulosic fibre type has statistically significant effect on Cvm\% of yarn samples. $\mathrm{R}$ squared for Quadratic Model is found to be as $83 \%$.

\section{Imperfection index (IPI)}

The cumulative total of the values of thin places $(-50 \% / \mathrm{km})$, thick places $(+50 \% / \mathrm{km})$ and neps $(+200 \% / \mathrm{km})$ of cotton and polyester blended ring spun yarn samples were determined and the results graphs is given in figure 4. Upon the examination of fibre type $\left(\right.$ Viloft $^{\circledR}$, Promodal ${ }^{\circledR}$ and Bamboo), Viloft ${ }^{\circledR}$ fibre has the highest IPI values for polyester blend than that of the other fibre types. The linear density of Viloft ${ }^{\circledR}$ is 1.9 dtex and due to having a flat cross section and crenulated surface, Viloft ${ }^{\circledR}$ fibre can resist the packing of yarn, it means that imperfection can probably occur in the cross section of the yarn [11]. For the rest of fibre types, Promodal ${ }^{\circledR}$ and Bamboo

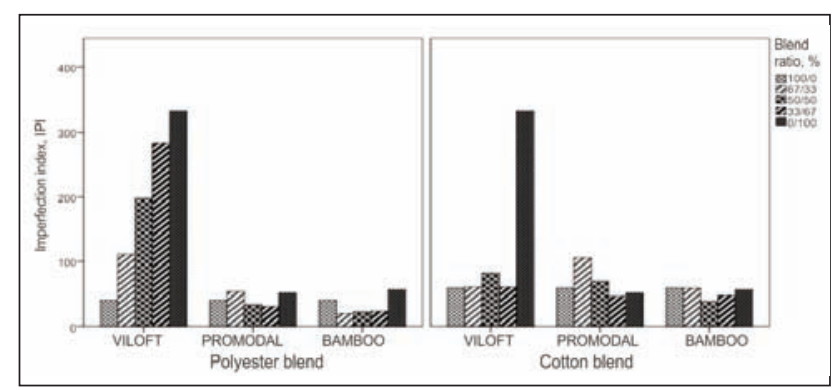

Fig. 4. IPI of polyester and cotton blended yarns

\begin{tabular}{|c|c|c|c|c|c|}
\hline \multicolumn{6}{|c|}{$\begin{array}{c}\text { ANOVA RESULTS FOR RESPONSE 2FI MODEL } \\
\text { FOR IPI OF YARNS }\end{array}$} \\
\hline Source & $\begin{array}{l}\text { Sum of } \\
\text { square }\end{array}$ & DF & $\begin{array}{l}\text { Mean } \\
\text { square }\end{array}$ & \begin{tabular}{|c|}
$F$ \\
value
\end{tabular} & $p$-value \\
\hline Model & $1.762 \mathrm{E}+005$ & 9 & 19575.08 & 9.13 & $<0.0001$ \\
\hline $\begin{array}{l}\text { A-Blend } \\
\text { Type }\end{array}$ & 2851.88 & 1 & 2851.88 & 1.33 & 0.2623 \\
\hline $\begin{array}{l}\text { B-Fibre } \\
\text { Type }\end{array}$ & 71288.49 & 2 & 35644.24 & 16.63 & $<0.0001$ \\
\hline $\begin{array}{l}\text { C-Blend } \\
\text { Ratio }\end{array}$ & 32692.54 & 1 & 32692.54 & 15.25 & 0.0009 \\
\hline $\mathrm{AB}$ & 11960.60 & 2 & 5980.30 & 2.79 & 0.0853 \\
\hline$A C$ & 2496.10 & 1 & 2496.10 & 1.16 & 0.2933 \\
\hline $\mathrm{BC}$ & 54886.15 & 2 & 27443.08 & 12.80 & 0.0003 \\
\hline Residual & 42864.16 & 20 & 2143.21 & & \\
\hline Cor Total & $2.190 \mathrm{E}+005$ & 29 & & & \\
\hline
\end{tabular}


blended yarns show lower and similar IPI values. When the fibre blend parameter is taken into consideration, pure polyester yarn has lower IPI value than that of pure cotton yarns.

As seen in table 5, when the analyzing of factorial design of $2 \mathrm{FI}$ Model ANOVA results, it is found that blend type has not statistically significant effect on IPI value $(p=0.2623)$. Because there is no difference between polyester and cotton blended yarns IPI values at $95 \%$ significance level. On the other hand, fibre type and blend ratio have statistically significant effect on IPI value and R squared for this model was estimated as $80 \%$ as a high value.

\section{Hairiness}

Hairiness values of ring spun blended yarn samples determined with Uster ${ }^{\circledR}$ Tester 4 as Uster $^{\circledR} \mathrm{H}$ value is given in figure 5 . When the increase in the regenerated cellulosic fibre content is considered, hairiness value changes are found to be different according to the fibre type. Similar with IPI values of Viloft ${ }^{\circledR}$ blended polyester ring spun yarns, hairiness value of yarn also increases from lower to higher Viloft ${ }^{\circledR}$ content except $50 \% / 50 \%$ blend ratio. In contrast to Viloft $^{\circledR}$ blended yarns, bamboo rich polyester blended yarns have lower hairiness value than that of pure polyester yarn. This result is seen as similar to cotton-bamboo blended yarns in general. Furthermore, hairiness values of pure ProModal ${ }^{\circledR}$ and pure polyester yarn are seems to be close to each other and the difference is low. On the other hand, it can be said that Promodal ${ }^{\circledR}$ and Bamboo content has decreasing effect on hairiness values of cotton blend ring spun yarns. In addition, pure cotton yarn has higher hairiness than pure polyester yarn because cotton is natural fibre. Because of the circular cross-section of the polyester fibre leads to more compactness thus the number of free ends per unit length of the yarn can reduce.

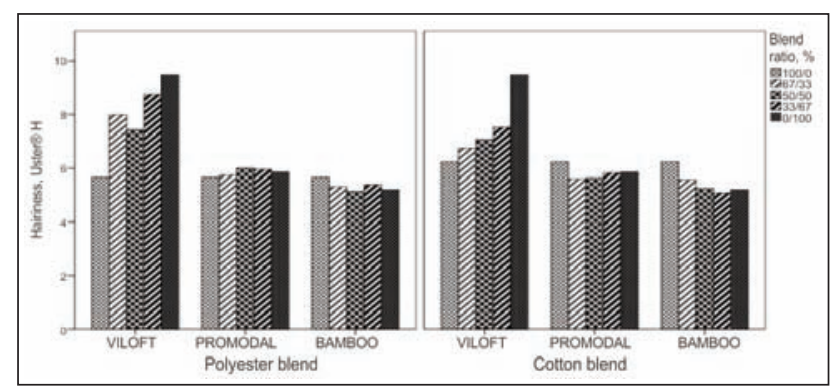

Fig. 5. Hairiness of polyester and cotton blended yarns

2FI model was chosen as suggested model for the ANOVA analysis of the hairiness (table 6). Results show that blend type (polyester and cotton) has not statistically significant effect with $p=0.4158$. On the other hand, fibre type and blend ratio was found to be statistically significant $(p<0.0001)$. The highest effect is obtained with fibre type with the $F$ value of 119.14 . It is probably concluded that $2 \mathrm{FI}$ model can explain the hairiness of yarn samples with the highest value of $95 \% \mathrm{R}$ squared.

\begin{tabular}{|l|c|c|c|c|c|}
\hline \multicolumn{6}{|c|}{ ANOVA RESULTS FOR RESPONSE 2FI MODEL } \\
FOR HAIRINESS OF YARNS \\
\hline Source & $\begin{array}{c}\text { Sum of } \\
\text { square }\end{array}$ & DF & $\begin{array}{c}\text { Mean } \\
\text { square }\end{array}$ & $\begin{array}{c}\text { F } \\
\text { value }\end{array}$ & p-value \\
\hline Model & 45.31 & 9 & 5.03 & 40.75 & $<0.0001$ \\
\hline $\begin{array}{l}\text { A-Blend } \\
\text { Type }\end{array}$ & 0.085 & 1 & 0.085 & 0.69 & 0.4158 \\
\hline $\begin{array}{l}\text { B-Fibre } \\
\text { Type }\end{array}$ & 29.45 & 2 & 14.72 & 119.14 & $<0.0001$ \\
\hline $\begin{array}{l}\text { C-Blend } \\
\text { Ratio }\end{array}$ & 2.99 & 1 & 2.99 & 24.20 & $<0.0001$ \\
\hline AB & 0.48 & 2 & 0.24 & 1.93 & 0.1706 \\
\hline AC & 0.27 & 1 & 0.27 & 2.15 & 0.1581 \\
\hline BC & 12.05 & 2 & 6.02 & 48.76 & $<0.0001$ \\
\hline Residual & 2.47 & 20 & 0.12 & & \\
\hline Cor Total & 47.79 & 29 & & & \\
\hline
\end{tabular}

\section{Quality optimization}

In order to optimize the yarn quality, numerical optimization method was used to find a point that maximizes the desirability function. Desirability is an objective function to the target that ranges from the zero outside of the limits to one at the goal. Desirability method makes use of an objective function, $\mathrm{D}(\mathrm{X})$, called the desirability function. This function reflects the desirable ranges for each response $\left(d_{i}\right)$ and desirable ranges changes from 0 to 1 which corresponds least to most desirable and involves the use of a geometric mean of individual desirability [23-25]. For various responses and factors, all targets are combined as a desirability function. The simultaneous objective function is a geometric mean of all transformed responses which is defined as equation (1) given below.

$$
D=\left(d_{1} \times d_{2} \times \ldots \times d_{n}\right)^{\frac{1}{n}}=\left(\prod_{i=1}^{n} d_{i}\right)^{\frac{1}{n}}
$$

Where $n$ is the number of responses in the measure. If any of the responses or factors fall outside their desirability range, the overall function becomes zero [25]. In determining desirability function, the importance $\left(r_{j}\right)$ of each response which varies from least important $(+)$ to the most important $(+++++)$ can be assigned relative to the other responses. The objective function is estimated as equation (2) if varying degrees of importance are assigned to the different responses.

$$
D=\left(d_{1}^{r_{1}} \times d_{1}^{r_{2}} \times \ldots \times d_{1}^{r_{n}}\right)^{\frac{1}{\sum r_{i}}}=\left(\prod_{i=1}^{n} d_{1}^{r_{i}}\right)^{\frac{1}{\sum r_{i}}}
$$

Where $n$ is the number of responses in the measure. If an individual response is to be maximized, the individual desirability is defined as the following formulas:

$$
\begin{aligned}
& d_{i}=0 \rightarrow Y_{i} \leq \operatorname{Low}_{i} \\
& d_{i}=\left[\frac{Y_{i}-\operatorname{Low}_{i}}{\text { High }_{i}-\operatorname{Low}_{i}}\right]^{w t_{i}} \rightarrow \operatorname{Low}_{i} \leq Y_{i} \leq \operatorname{High}_{i}
\end{aligned}
$$




$$
d_{i}=1 \rightarrow Y_{i} \geq \operatorname{High}_{i}
$$

For goal of minimum, the desirability will be explained by the following formulas:

$$
\begin{aligned}
& d_{i}=1 \rightarrow Y_{i} \leq \text { Low }_{i} \\
& d_{i}=\left[\frac{\text {High }_{i}-Y_{i}}{\text {High }_{i}-\text { Low }_{i}}\right]^{w t_{i}} \rightarrow \operatorname{Low}_{i} \leq Y_{i} \leq \text { High }_{i} \\
& d_{i}=0 \rightarrow Y_{i} \geq \text { High }_{i}
\end{aligned}
$$

The shape of the desirability can be changed in accordance with each goal by the 'weight' field. It should be used weights to give added emphasis to the upper/lower bounds. With a weight of 1 the $d_{i}$ will vary from 0 to 1 in a linear fashion. Weights greater than 1 (maximum weight is 10 ), give more emphasis to the goal. Weights less than 1 (minimum weight is 0.1 ), give less emphasis to the goal [23]. Desirability curves for goal is maximum, minimum and within the range is illustrated in figure 6 .

Before the achieving the numerical optimization of blended ring spun yarns, the constraints of independent parameters (blend type, fibre type and blend ratio) were determined according to the expectation functions/properties from these yarns. The weight of

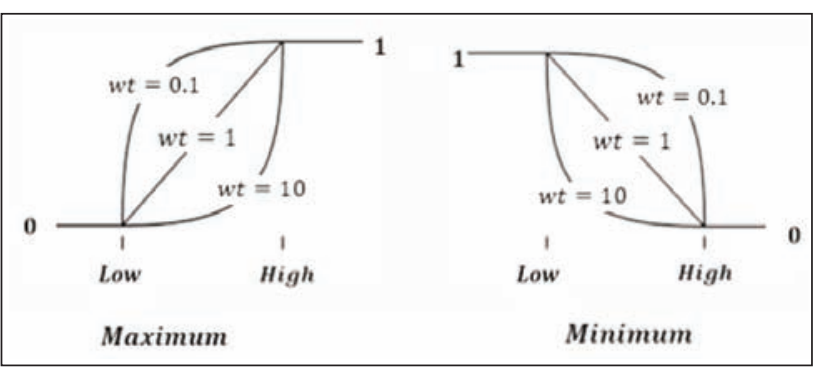

Fig. 6. Desirability curves for goal is maximum or minimum [23]

importance and desired goal of independent variables and response variables are illustrated in table 7. Tenacity and elongation values of the blended yarns were taken as 'Maximize'; on the other hand, $\mathrm{CVm} \%$, IPI and hairiness were taken as 'Minimize'.

The overall desirability values of the multi response numerical optimization results are given in table 8. Here, the desirability represents 'Overall Desirability' including all response variables that the highest overall desirability value is ' 1 ' and the lowest one is ' 0 '.

As clearly seen in table 8 first line (No.1), the highest the value of the overall desirability can be understood as how well the specified goals are achieved and how well all the goals are met [24]. This line clarifies

\begin{tabular}{|l|c|c|c|c|c|c|}
\hline \multicolumn{7}{|c|}{ INDEPENDENT AND RESPONSE VARIABLES } \\
\hline \multicolumn{1}{|c|}{ Name } & Goal & Lower limit & Upper limit & Lower weight & Upper weight & Importance \\
\hline A-Blend Type & Is in range & Polyester & Cotton & 1 & 1 & 3 \\
\hline B-Fibre Type & Is in range & Viloft ${ }^{\circledR}$ & Bamboo & 1 & 1 & 3 \\
\hline C-Blend Ratio & Is in range & 0 & 100 & 1 & 1 & 3 \\
\hline Tenacity, cN/tex & Maximize & 9.562 & 27.431 & 1 & 1 & 5 \\
\hline Elongation, \% & Maximize & 5.013 & 12.718 & 1 & 1 & 3 \\
\hline Unevenness, Cvm\% & Minimize & 11.39 & 17 & 1 & 1 & 5 \\
\hline Imperfection Index, IPI & Minimize & 19.5 & 332.35 & 1 & 1 & 3 \\
\hline Hairiness, Uster ${ }^{\circledR} \mathrm{H}$ & Minimize & 5.08 & 9.7 & 1 & 1 & 5 \\
\hline
\end{tabular}

Table 8

\begin{tabular}{|c|c|c|c|c|c|c|c|c|c|}
\hline \multicolumn{9}{|c|}{ MULTI RESPONSE NUMERICAL OPTIMIZATION RESULTS } \\
\hline No & $\begin{array}{c}\text { A-Blend } \\
\text { Type }\end{array}$ & $\begin{array}{c}\text { B-Fibre } \\
\text { Type }\end{array}$ & $\begin{array}{c}\text { C-Blend } \\
\text { Ratio }\end{array}$ & $\begin{array}{c}\text { Tenacity } \\
\text { (cN/tex) }\end{array}$ & $\begin{array}{c}\text { Elonga- } \\
\text { tion } \\
(\%)\end{array}$ & $\begin{array}{c}\text { Unevenness } \\
\text { Cvm } \\
(\%)\end{array}$ & $\begin{array}{c}\text { Imperfec- } \\
\text { tion Index, } \\
\text { IPI }\end{array}$ & $\begin{array}{c}\text { Hairiness, } \\
\text { Uster }\end{array}$ & Hesirability \\
\hline 1 & Polyester & Bamboo & 73.193 & 25.199 & 11.095 & 12.721 & 24.176 & 5.439 & 0.859 \\
\hline 2 & Polyester & Bamboo & 73.479 & 25.238 & 11.095 & 12.731 & 24.083 & 5.440 & 0.859 \\
\hline 3 & Polyester & Bamboo & 72.561 & 25.115 & 11.094 & 12.698 & 24.381 & 5.436 & 0.859 \\
\hline 4 & Polyester & Bamboo & 71.930 & 25.030 & 11.093 & 12.677 & 24.586 & 5.433 & 0.859 \\
\hline 5 & Polyester & ProModal ${ }^{\circledR}$ & 67.419 & 25.010 & 9.671 & 13.264 & 64.245 & 5.780 & 0.768 \\
\hline 6 & Cotton & ProModal $^{\circledR}$ & 0.0000 & 18.926 & 8.395 & 13.212 & 58.380 & 5.673 & 0.659 \\
\hline 7 & Polyester & Viloft $^{\circledR}$ & 98.236 & 25.747 & 11.300 & 15.902 & 44.882 & 6.039 & 0.601 \\
\hline 8 & Cotton & Bamboo $^{\text {I }}$ & 11.972 & 12.951 & 9.606 & 13.427 & 43.566 & 5.080 & 0.555 \\
\hline 9 & Cotton & Viloft $^{\circledR}$ & 60.321 & 11.719 & 5.503 & 13.691 & 92.899 & 7.112 & 0.302 \\
\hline
\end{tabular}




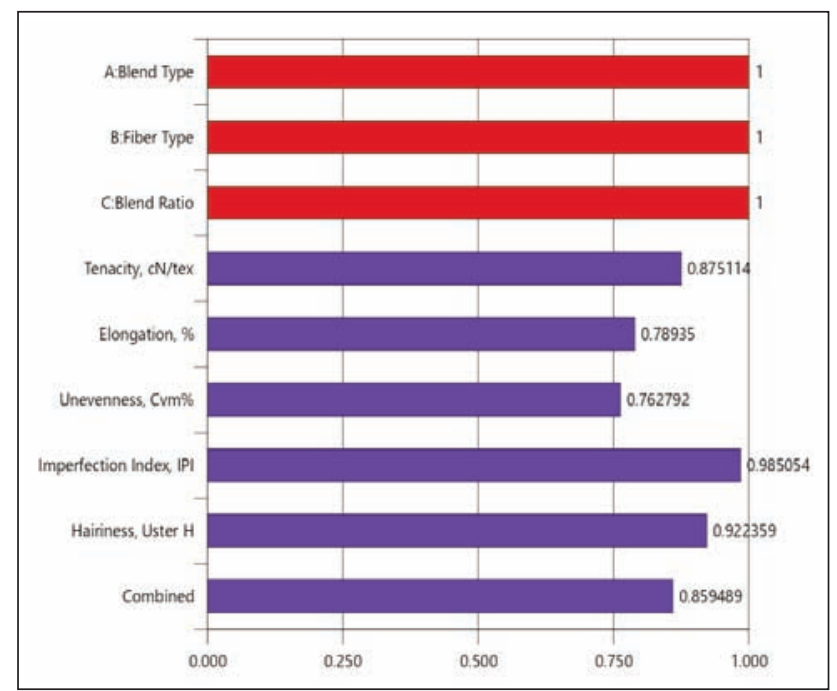

Fig. 7. Individual desirability values of response variables for 0.859 overall desirability

maximum level of tenacity, elongation and minimum level of unevenness, IPI and hairiness which importance of these are predefined in the numerical optimization process. From the line 1, if polyester/ bamboo blended yarn with $73.19 \% / 26.81 \%$ blend ratio is used; overall desirability with the value of 0.859 will meet the goal. It seems as polyester blended regenerated cellulosic fibres are suitable in terms of desired goals, but cotton blended regenerated cellulosic fibres will have lower capability for achieving the goals. Furthermore, table 8 exhibits the optimum blend type, fibre type and blend ratio to attain the desired response variables. Table 8 also exhibits the obtained response variables of tenacity, elongation, unevenness, IPI and hairiness for every desirability value. In that point, the least desirable yarn type was found to be cotton/Viloft ${ }^{\circledR}$ with $60.3 \% / 39.7 \%$ blend ratio at 0.302 desirability value. As clearly seen in the analysis, the desirability of polyester/Viloft ${ }^{\circledR}$ and cotton/Viloft ${ }^{\circledR}$ yarn types are lower than the other regenerated cellulosic fiber types because of Viloft ${ }^{\circledR}$ fiber characteristics which affect the yarn quality directly such as Cvm\% and hairiness. As a conclusion, the best desirability will be obtained from polyester/bamboo blended ring spun yarns with high polyester content. In addition, individual desirability of each response variables can be practiced by means of Design Expert package program. Figure 7 gives the each response variables desirability for the best results of numerical optimization. As seen in figure 7 , the overall desirability is shown as 'Combined' with 0.859 value. Among response variables, the highest desirability is obtained from IPI (0.985). The second highest desirability is determined as hairiness. Desirability of tenacity, elongation and unevenness are found as $0.875,0.789$ and 0.762 , respectively.

\section{CONCLUSION}

The progress in the production of new regenerated cellulosic fibres is growing rapidly.
Especially, regenerated cellulosic fibres are preferred as knitted summer clothes because of their thermal comfort properties and they can be blended at different proportion with natural or synthetic fibres. In this study, Viloft ${ }^{\circledR}$, ProModal $^{\circledR}$ and bamboo regenerated cellulosic fibres were blended with cotton and polyester fiber with different ratios to produce ring spun yarns. Firstly, the tensile strength and elongation, unevenness, IPI and hairiness properties were determined. In addition, the effects of blend type (Polyester and Cotton), fibre type (Vilof ${ }^{\circledR}$, ProModal ${ }^{\circledR}$ and Bamboo) and blend ratio (100\%, 67/33\%, $50 / 50 \%, 33 / 67 \%$ ) parameters on yarn properties were analyzed statistically. Secondly, importance levels of these yarn properties were defined according to the desired goal of response variables in the design in order to achieve numerical optimization of the yarn. Results can be summarized as follows:

- When tensile strength properties of ring spun yarns are taken into consideration, blend type, fiber type and blend ratio have statistically significant effects on tenacity of regenerated/polyester and regenerated/cotton yarns. In addition, the least tenacity value was obtained with pure Viloft ${ }^{\circledR}$ yarn among the other type of regenerated cellulosic fibres. Though regenerated cellulosic fibre content contributes the breaking elongation of cotton blended yarns, for the polyester blend yarns, it was not observed that there is a regular tendency for all regenerated cellulosic fibre type.

- It was found that Viloft ${ }^{\circledR}$ blended yarns had the worst unevenness and IPI values for polyester blend types. Similarly, it is determined that Viloft ${ }^{\circledR}$ blended polyester and cotton yarns had the higher hairiness value.

- In order to determine the best desirability function according to the blend type, fiber type and blend ratio, the importance and levels of the response variables were defined and numerical optimization was achieved. As 'Maximize' function tenacity and elongation were selected because these parameters must be higher during the fabric production and usage stage. On the other hand, unevenness, IP and hairiness which are important features that prevent working comfortably with these yarns in fabric production. And also, these affect the fabric performance and aesthetic properties negatively. So these response variables were taken as 'Minimize' as desired goal. Numerical optimization results show that, for bamboo polyester blended yarn with $73.19 \%$ polyester proportion had the highest desirability (0.859).

\section{ACKNOWLEDGEMENTS}

The authors would like to thank to SANKO Textile Research and Development Center for producing yarn samples and making tensile strength and elongation, unevenness and hairiness measurements. 


\section{BIBLIOGRAPHY}

[1] Majumdar, A., Mukhopadhyay, S., Yadav, R., Mondal, A.K., Properties of ring spun yarns made from cotton and regenerated bamboo fibres, In: Indian Journal of Fibre \& Textile Research, 2011, 36, pp. 18-23

[2] Prakash, C., Ramakrishman, G., Koushik, C.V., Effect of blend ration on quality characteristics of bamboo/cotton blended ring spun yarn, In: Daffodil International University Journal of Science and Technology, 2012, 7, 1, pp. 34-37

[3] Sekerden, F., Investigation on the unevenness, tenacity and elongation properties of bamboo/cotton blended yarns, In: Fibres\&Textiles in Eastern Europe, 2011, 19, 3, pp. 26-29

[4] Demiryürek, O., Kılıç, A., An investigation on the unevenness, hairiness and friction coefficient properties of cottonbamboo blended ring-spun yarns, In: Industria Textila, 2018, 69, 3, pp. 235-242

[5] Malik, S.A., Tanwari, A., Syed, U., Qureshi, R.F., Mengal, N., Blended yarn analysis: Part I - influence of blend ratio and break draft on mass variation, hairiness and physical properties of 15 tex PES/CO blended ring-spun yarn, In: Journal of Natural Fibers, 2012, 9, 3, pp. 197-206

[6] Canoglu, S., Tanir, S.K., Studies on yarn hairiness of polyester/cotton blended ring-spun yarns made of different blend ratios, In: Textile Research Journal, 2009, 79, 3, pp. 235-242

[7] Ahmad, I., Farooq, A., Baig, S.A., Rashid, M.F., Quality parameters analysis of ring spun yarns made from different blends of bamboo and cotton fibres, In: Journal of Quality and Technology Management, 2012, 8, 1, pp. 1-12

[8] Koç, E., Demiryürek, O., Predicting the tensile strength of polyester/viscose blended open-end rotor spun yarns using artificial neural network and statistical models, In: Industria Textila, 2011, 62, 2, pp. 87

[9] Kilic, M., Okur, A., The properties of cotton-Tencel and cotton-Promodal blended yarns spun in different spinning systems, In: Textile Research Journal, 2011, 81, 2, pp. 156-172

[10] Demiryürek, O., Uysaltürk, D., Thermal comfort properties of viloft/cotton and viloft/polyester blended knitted fabrics, In: Textile Research Journal, 2013, 83, 16, pp. 1740-1753

[11] Demiryürek, O., Uysaltürk, D., Statistical analyses and properties of viloft/polyester and viloft/cotton blended ringspun yarns, In: Fibres\&Textiles in Eastern Europe, 2014, 22, 1(103), pp. 22-27

[12] Atasagun, H.G., Öner, E., Okur, A., Beden, A.R., A comprehensive study on the general performance properties of Viloft-blended knitted fabrics, In: The Journal of Textile Institute, 2015, 106, 5, pp. 1-13

[13] North, M., Engineered viscose fibres delivering enhanced wearer comfort and fabric performance, In: Lenzinger Berichte, 2011, 89, pp. 37-42

[14] http://www.kelheim-fibres.com/produkte/vi_te_uk.php, Assessed 11 March 2018

[15] http://www.textileworld.com/Issues/2008/November-December/Knitting-Apparel/Lenzing_Launches_ProModal_ Blended_Fiber, Assessed 03 May 2018

[16] http://www.samil-sp.co.kr/UploadFiles/board/ds0001/1.22213069573E+13001.pdf, Assessed 15 March 2018

[17] Saravan, K., Prakash, C., Bamboo fibres\& their application in textiles, In: The Indian Textile Journal, 2007, 117, pp. 33-36

[18] BS EN ISO 139:2005+A1:2011 Textiles. Standard atmospheres for conditioning and testing

[19] ISO 16549:2004 Textiles. Unevenness of textile strands - Capacitance method

[20] BS EN ISO 2062:2009 Textiles. Yarns from packages. Determination of single-end breaking force and elongation at break using constant rate of extension (CRE) tester

[21] Chattopadhyay, R., Tyagi, G.K., Goyal, A., Studies of the hybrid effect in mechanical properties of tencel blended ring-, rotor-, and air-jet spun yarns, In: The Journal of the Textile Institute, 2013, 104, 3, pp. 339-349

[22] Saville, B.P. Physical testing of textiles, Woodhead Publishing Ltd and CRC Press LLC 1999

[23] Kaynak, H.K. Optimization of stretch and recovery properties of woven stretch fabrics, In: Textile Research Journal, 2017, 87, 5, pp. 582-592

[24] Kaynak, H.K., Babaarslan, O., Duru Baykal, P., Multi-response optimization of thermophysiological comfort properties of polyester filament woven fabrics, In: Journal of Textile Institute, 2017, 108, 10, pp. 1669-1681.

[25] Stat-Ease, www.statease.com. Accessed 05 July 2018

\section{Authors: \\ ESIN SARIOĞLU \\ Gaziantep University}

Faculty of Fine Arts, Department of Fashion and Textile Design

Sehitkamil-27310, Gaziantep, Turkey

e-mail: sarioglu@gantep.edu.tr

Corresponding author:

ESIN SARIOĞLU

e-mail: sarioglu@gantep.edu.tr 